\title{
「Comparison Between Theory and Experiment of the Oscillation of a Rectangular Cylinder in a Grid-Generated Uniform Turbulence」に対する討論
}

\author{
（森 武雄著, 日本建築学会論文報告集，第 285 号，昭和 54 年 11 月掲載）
}

正会員田村 幸雄*

森氏の論文を興味媣く読ませていただきました。論文 中で疑義のある点を二，三質問させていただきます。

\section{1）風向直角方向振動の理論解の導入について}

変動揚力のスペクトルから応答スペクトルを通常の線 形共振系として求めておられますが, 森氏の仮定されて いる様に，カルマン渦による变動揚力が支配的であると すれば，多くの渦励振実験結果はその様な立式に対して 肯定的であるとは言えません。渦励振を純粋に抜き出し て研究されているのは，断面の特徵から円断面に対する むのが殆んどですが，減衰比の大なる場合を除いて自励 的な側面の強いものであります。又, Ferguson ${ }^{1}$ 等の実 験でも知られる様に，揚力のピークと応答のピークは必 ずしも一致して拈りません。これらのことは, 強制振動 的な取扱い，スペクトル解析で用いる通常の重致合わせ を否定し，更に揚力と応答が一意的には結びっかないこ とを意味しています。この揚力と応答が一意的には結び つかないことは，渦励振を考える上で，応答の履歴の影 響が重要であることを示唆しており，従来の理論的な取 扱いで久落している点であります。少なくとも，渦励振 に着目して考える場合は，揚力を与えて応答を知るとい う単純な関係で把えることはできないと思われます。以 上のことは，渦励振応答が大きくなる様な場合程顕著に 影響するもので，応答が小さくなる様な場合は，近似的 に通常の線形系の強制振動的取扱いが可能であることは 推定されます。スペクトル的取扱いはランダムな現象に 対して有力な方法でありますから，その手法を発展させ

* 早稲田大学専門学校 講師

（昭和 54 年 11 月 28 日本稿受理）
ることは必要であると考えますが，(18）式，(19）式の 導入は安易にすぎるのではないかと思われます。

勿論, 従来の角柱の直角方向振動の研究で踏襲されて きた方法に立脚されたものと思われますし，渦励振現象 の形状による多栐性等を考慮すると一概には言えません が，今一度考慮が必要ではないでしょうか。

2) 4. Discussions and conclusions において 森氏は変動揚力のスペクトルが $f B / U=0.14$ で狭い ピークを持っているから $U / f_{0} B=7$ より離れた風速で の振動は渦発生とは関係のない変動揚力により起こった のであろら」と述べられておりますが，「スペクトルの ピークが狭い」ことから即座に言いきれることではない と考えます。通常の線形系でも，たとえ単一周波数入力 であろらと共振点以外での応答は 0 にはならないのです から，判断の基準はスペクトルのピークが狭いか広いか ではなく, カルマン渦による振動成分と，風速の直角方 向の乱れによる振動成分の $U / f_{0} B=7$ より離れた風速 でのオーダーの比較でなくてはなりません。図一10に 実験值をプロットされた風速範囲では, 前者が後者より 著しく小さいとは言い難いのではないでしょうか。

以上の点は（27）式，(30）式が実験值をかなり下ま わったことの原因の一っだと思いますので，森氏の見解 を聞かせていただければ幸いです。

\section{参 考 文 献}

1) Ferguson \& Parkinson: "Surface and Wake Flow Phenomena of the Vortex-Excited Oscillation of a Circular Cylinder", Trans. ASME, J. Eng. Ind., 89, 1967 